\title{
A Demand Systems Analysis of Food Commodities by U.S. Households Segmented by Income
}

\author{
John L. Park; Rodney B. Holcomb; Kellie Curry Raper; Oral Capps, Jr. \\ American Journal of Agricultural Economics, Vol. 78, No. 2. (May, 1996), pp. 290-300.
}

Stable URL:

http://links.jstor.org/sici?sici=0002-9092\%28199605\%2978\%3A2\%3C290\%3AADSAOF\%3E2.0.CO\%3B2-V

American Journal of Agricultural Economics is currently published by American Agricultural Economics Association.

Your use of the JSTOR archive indicates your acceptance of JSTOR's Terms and Conditions of Use, available at http://www.jstor.org/about/terms.html. JSTOR's Terms and Conditions of Use provides, in part, that unless you have obtained prior permission, you may not download an entire issue of a journal or multiple copies of articles, and you may use content in the JSTOR archive only for your personal, non-commercial use.

Please contact the publisher regarding any further use of this work. Publisher contact information may be obtained at http://www.jstor.org/journals/aaea.html.

Each copy of any part of a JSTOR transmission must contain the same copyright notice that appears on the screen or printed page of such transmission.

The JSTOR Archive is a trusted digital repository providing for long-term preservation and access to leading academic journals and scholarly literature from around the world. The Archive is supported by libraries, scholarly societies, publishers, and foundations. It is an initiative of JSTOR, a not-for-profit organization with a mission to help the scholarly community take advantage of advances in technology. For more information regarding JSTOR, please contact support@jstor.org. 


\title{
A Demand Systems Analysis of Food Commodities by U.S. Households Segmented by Income
}

\author{
John L. Park, Rodney B. Holcomb, Kellie Curry Raper, \\ and Oral Capps, Jr.
}

\begin{abstract}
Using the 1987-88 Nationwide Food Consumption Survey, twelve food commodity groups were analyzed according to household poverty status. Parameter estimates were used to obtain subsistence expenditures, own-price elasticities, expenditure elasticities, and income elasticities. Own-price elasticities were similar between the income groups for most commodities. However, income elasticities were consistently higher for the lower-income group. The use of average estimates of price and income elasticities for the population as a whole for the projection of individual commodity demands is not likely to be successful if notable changes are evident in income distribution.
\end{abstract}

Key words: food demand analysis, Generalized Heckman Procedure, income, poverty status.

At present, greater numbers of households fall into either the "low-income" category or the "high-income" category, resulting in what the media refers to as the "shrinking middle class." Raunikar, Huang, and Purcell point out (p. 43) that "prior to the 1980s, the trend was toward the relative enhancement of lower-income groups via a shift in income to improve their purchasing power... However, this trend was reversed in the 1980s with a shift in the income distribution toward higher-income groups."

It is possible that lower-income households may respond differently to changes in prices and income than higher-income households. As Pinstrup-Andersen and Caicedo note (p. 414), "the utilization of average estimates of price and income elasticities for the population as a whole for the projection of individual commodity demands is not likely to be very successful

\footnotetext{
John L. Park is research associate in the Food Industry Management Program at Cornell University. Rodney B. Holcomb is research associate and Oral Capps, Jr. is professor, both in the Department of Agricultural Economics at Texas A\&M University. Kellie Curry Raper is assistant professor in the Department of Resource Economics at the University of Massachusetts.

Senior authorship is not assigned. The authors wish to acknowledge comments made by Benjamin Senauer on a previous draft. Any errors or omissions are the sole responsibility of the authors.
}

if significant changes occur in income distribution." Based on the work of Pinstrup-Anderson and Caicedo, we hypothesize that in societies such as the United States, where visible changes have occurred in income distribution, commodity demand projections should be based on individual income strata rather than on average estimates of price and income elasticities. Also, it is reasonable to expect different levels of "subsistence expenditure" for groups segmented by income. This information may be useful to policy analysts, particularly those involved with government food assistance programs; in general these programs have been targeted at low-income groups.

Previous empirical work on groups segmented by income in the extant literature has focused on developing countries and staple foods. Senauer reported that lower-income households are more price and income responsive for the consumption of rice in various developing countries. Timmer found a similar result for the consumption of rice and cassava among lower-income households in Indonesia. In contrast to the United States, households in developing countries can spend $60 \%-80 \%$ of their income on food. Also, 40\%-60\% of food expenditures can be accounted for by one staple food (Senauer). 
However, there is no reason to believe that previous results for developing countries will hold for developed countries such as the United States. Several studies have examined differences in household behavior for income groups in the United States. Blaylock and Blisard, for example, discovered food spending to be more equally distributed than income, possibly due to subsistence requirements and government efforts to provide an adequate diet. In a study of expenditures on breakfast cereals, Jones, Chern, and Mustiful found lower-income groups to be more responsive to changes in price than higher-income groups. This study, however, was confined to a specific geographic location and commodity group. In addition, data limitations prevented analysis of income responsiveness. In another study, Huang and Raunikar showed that food away from home was a luxury good for lower-income households and a normal good for higher-income households, but a measurement of price responsiveness was lacking.

In the literature on demand analysis, there exists a myriad of studies which report estimates of own-price and income elasticities for various commodities. However, few studies center attention on the fact that these key parameters may change at different levels of income. Our objective in this paper is to investigate possible differences in own-price elasticities, income elasticities, and subsistence expenditures by level of income. Using the 1987-88 Nationwide Food Consumption Survey (NFCS), we partition the sample into two income classes. Subsequently, using the Linear Expenditure System (LES), we estimate own-price and income elasticities for twelve food commodity groups. The LES was chosen for its incorporation of subsistence consumption; the system also works well for broad commodity groups. Quality-adjusted prices were used in this analysis to provide a fair comparison of two potentially distinct groups (Cox and Wohlgenant). We then compare the corresponding set of demand elasticities between the two groups. Because the results may be beneficial to federal agencies who target principally low-income groups, we provide examples of how to use the elasticity estimates in dealing with food policy issues.

\section{Data}

The data set for this analysis is the household portion of the 1987-88 NFCS, targeted at all private households in the forty-eight contiguous states. The survey was designed to provide a sample of 6,000 households. However, only 4,495 completed acceptable interviews. The data set provided detailed records on the money value, quantity, and type of foods purchased by the household over a one-week period. Our analysis considered only housekeeping households, that is, those households with at least one person having eaten ten or more meals from the household food supply during seven days prior to the interview. Also, some households failed to report income figures, or had nonresponses in other categories. These households were not used for analysis. On net, our sample consists of 4,068 households.

An additional fifty-two households were removed from the sample because they reported annual incomes less than $\$ 1,000$, which seemed unreasonable. Finally, only white, black, and Asian/Pacific Islander households were analyzed, providing a total sample of 3,869 households for estimation purposes.

A degree of controversy exists concerning the validity of the 1987-88 NFCS. In particular, the General Accounting Office has criticized these data on the grounds of low response rate and quality control. While it is true that the data may not adequately represent certain groups, the distribution of individuals on the basis of race, urbanization, food stamp participation, and income seems representative of the U.S. population in 1988 (Nayga and Capps).

Twelve aggregate commodity groups were chosen for this analysis: food away from home (FAFH), beef, pork, chicken, fish, cheese, milk, fruits, vegetables, breakfast cereals, bread, and fats and oils. Also, information was collected on various socioeconomic and demographic characteristics of households including income and household size.

Prices were not provided by the NFCS. Therefore, prices were imputed by dividing a group's expenditures by its corresponding quantities. In the case of FAFH, this quantity is an actual number of meals. Thus, the imputed price would represent the price of a meal away from home. Differences in these prices were attributed to quality differences. As Cox and Wohlgenant showed, adjusting prices for quality differences is important. Therefore, prices were subsequently adjusted for quality differences among households by regressing imputed prices on selected sociodemographic characteristics, namely race, region, urbanization, income, and household size, as follows: 


$$
\begin{aligned}
p_{i} & =b_{0}+b_{1} N E+b_{2} M W+b_{3} W E S T \\
& +b_{4} C C+b_{5} S U B+b_{6} B L A C K \\
& +b_{7} A S I A N+b_{8} I N C O M E+b_{9} H S I Z E+\varepsilon_{i}
\end{aligned}
$$

The variables include $p_{i}$, the imputed price of the $i$ th commodity group; $N E$, a binary variable representing a household located in the Northeast; $M W$, a binary variable representing a household located in the Midwest; WEST, a binary variable representing a household located in the West; $C C$, a binary variable representing a central city household; $S U B$, a binary variable representing a suburban household; BLACK, a binary variable representing a black household; ASIAN, a binary variable representing an Asian household; INCOME, annual income after taxes; and HSIZE, the household size. These variables are common to analyses of expenditure or Engel functions (Blaylock; Capps and Havlicek). One category was omitted from each demographic characteristic to avoid singularity due to the use of binary variables. Thus, reference households correspond to those that reside in the South, live in nonmetropolitan areas, and are white.

Quality-adjusted prices for each commodity were generated by adding $\hat{b}_{0}$ to the residuals derived from each commodity regression (Cox and Wohlgenant). This proceedure is common in the literature to generate quality-adjusted prices. Not all households purchased all commodities during the survey period. When either expenditure or quantity was zero, the qualityadjusted price was equal to $\hat{b}_{0}$ for that commodity group. ${ }^{1}$

The principal goal of this study was to analyze the effects of income level upon household food consumption behavior. To accomplish this goal, the data were partitioned into a low-income group and a high-income group. The basis for this segmentation was the $1987-88$ poverty guidelines as developed by the U.S. Department of Health and Human Services (DHHS) (table 1). These poverty guidelines are adapted from poverty thresholds published by the Bureau of Census. They are used by federal

\footnotetext{
1 As an anonymous reviewer pointed out, Wales and Woodland (p. 449) state that "although intuitively appealing and possibly useful for prediction purposes, this approach does not generally provide consistent estimates of parameters of the model due to sample selectivity and simultaneity problems." Even though we could apply the Heckman technique to overcome the sample selectivity problem to obtain consistent estimates of the parameters in equation (1), it appears impossible to derive consistent estimates of these parameters independently from those of equation (2) to be discussed later. Consequently, we use the traditional procedure to generate quality-adjusted prices.
}

Table 1. 1987-88 Food Program Eligibility Criterion

\begin{tabular}{ccc}
\hline $\begin{array}{c}\text { Household } \\
\text { Size } \\
\text { (Number } \\
\text { of People) }\end{array}$ & $\begin{array}{c}\text { 1987-88 } \\
\text { Poverty Income } \\
\text { Guidelines (\$) }\end{array}$ & $\begin{array}{c}\text { Poverty Status (\$) } \\
\text { (130\% of Poverty } \\
\text { Guidelines) }\end{array}$ \\
\hline 1 & 5,360 & 6,968 \\
2 & 7,240 & 9,412 \\
3 & 9,120 & 11,856 \\
4 & 11,000 & 14,300 \\
5 & 12,880 & 16,744 \\
6 & 14,760 & 19,188 \\
7 & 16,640 & 21,632 \\
8 & 18,520 & 24,076 \\
9 & 20,320 & 26,416 \\
10 & 22,120 & 28,756 \\
11 & 23,920 & 31,096 \\
12 & 25,720 & 33,436 \\
\hline
\end{tabular}

Source: U.S. Department of Health and Human Services.

agencies to determine whether a person or a family is financially eligible for assistance under a particular governmental program. The fundamental idea of poverty guidelines is to ensure a household can meet its food needs (Senauer, Asp, and Kinsey). The poverty income guidelines have been established for households from one to eight persons. In addition, DHHS calculated poverty-level income for households with more than eight members as the eight-person poverty income plus $\$ 1,800$ for each additional person. Several major federal food assistance programs use $130 \%$ of the poverty guideline to determine eligibility for benefits.

Partitioning the data in this manner resulted in the creation of a poverty status group that consisted of 782 households with an average annual before-tax income of $\$ 6,850$ (table 2 ), and a nonpoverty status group with 3,087 households with an average annual after-tax income of $\$ 33,244$ (table 3 ). Not only did this partitioning allow for the comparison of parameter estimates between different income levels, but also segmenting the data set in this manner showed that roughly one-fifth of the sample households were eligible for government food aid.

An analysis of the composition of the two groups as exhibited in table 4 revealed some interesting differences. Given this segmentation, $47 \%$ of households in the poverty group reside in the South. We also found that $52 \%$ of the nonpoverty households were classified as suburban households by the NFCS. Finally, white 
households accounted for $91 \%$ of the nonpoverty group, while black households accounted for $27 \%$ of the poverty group. Not surprisingly, mean expenditures on FAFH are notably higher for the nonpoverty group. Furthermore, looking at data densities, we see that $87 \%$ of nonpoverty households purchased FAFH, compared to only $60 \%$ of poverty households. In general, data densities were higher for the nonpoverty group.

The generation of quality-adjusted prices admits the possibility that some of the prices may be negative. This situation suggests that, after accounting for quality differences, one would have to pay a particular household to consume the good in question. Thirty-one households in the lower-income group had a negative qualityadjusted price for at least one commodity, corresponding to $4 \%$ of this sample. Sixteen households in the higher-income group had a negative quality-adjusted price for at least one commodity, corresponding to less than $1 \%$ of this sample. Negative quality-adjusted prices are sensible within the framework of this analysis. But, to determine to what extent the negative prices influence the parameter estimates, the LES was estimated with and without these prices. Because virtually no differences in parameter estimates were evident, the empirical results reported correspond to those derived by including negative quality-adjusted prices.

Table 2. Descriptive Statistics for Poverty Status Households $(\boldsymbol{n}=\mathbf{7 8 2})$

\begin{tabular}{|c|c|c|c|c|c|}
\hline Variable & Mean & $\begin{array}{c}\text { Standard } \\
\text { Deviation }\end{array}$ & Data Densitya & Minimum & Maximum \\
\hline \multicolumn{6}{|c|}{ Expenditures } \\
\hline FAFH & 12.1520 & 22.1430 & 0.6010 & 0 & 249 \\
\hline Beef & 5.3299 & 6.0227 & 0.8031 & 0 & 62 \\
\hline Pork & 3.2852 & 4.6263 & 0.6253 & 0 & 34 \\
\hline Chicken & 2.0780 & 2.4667 & 0.6599 & 0 & 19 \\
\hline Fish & 2.0000 & 4.7149 & 0.4604 & 0 & 64 \\
\hline Cheese & 1.7046 & 2.2808 & 0.6304 & 0 & 15 \\
\hline Milk & 2.9041 & 3.1145 & 0.8619 & 0 & 29 \\
\hline Fruits & 2.0908 & 2.4993 & 0.6701 & 0 & 19 \\
\hline Vegetables & 2.3798 & 2.6075 & 0.7519 & 0 & 22 \\
\hline Breakfast cereals & 1.7826 & 2.2286 & 0.6535 & 0 & 17 \\
\hline Bread & 1.3824 & 1.3954 & 0.7685 & 0 & 10 \\
\hline Fats and oils & 1.3478 & 1.4541 & 0.6905 & 0 & 9 \\
\hline \multicolumn{6}{|c|}{ Quality-Adjusted Prices } \\
\hline FAFH & 3.9574 & 3.1314 & - & $-1.7818^{b}$ & 37.5490 \\
\hline Beef & 1.5261 & 0.5361 & - & 0.4175 & 4.9332 \\
\hline Pork & 1.7028 & 0.4699 & - & 0.4016 & 4.0394 \\
\hline Chicken & 1.0321 & 0.5312 & - & 0.0380 & 4.8640 \\
\hline Fish & 2.4785 & 0.7097 & - & $-0.3469^{c}$ & 9.2928 \\
\hline Cheese & 1.7182 & 0.5361 & - & 0.3716 & 5.0175 \\
\hline Milk & 0.3581 & 0.1666 & - & 0.1109 & 3.0077 \\
\hline Fruits & 0.5831 & 0.2135 & - & 0.1121 & 1.9804 \\
\hline Vegetables & 0.7226 & 0.2217 & - & 0.1600 & 2.0649 \\
\hline Breakfast cereals & 1.5740 & 0.5124 & - & $-0.4031^{\mathrm{d}}$ & 4.6309 \\
\hline Bread & 0.9245 & 0.2739 & - & 0.2683 & 2.9350 \\
\hline Fats and oils & 1.0283 & 0.3551 & - & 0.2922 & 3.1271 \\
\hline \multicolumn{6}{|c|}{ Socioeconomic Variables } \\
\hline Income & 6,850 & 3,570 & - & 1,052 & 29,200 \\
\hline Household size & 2.5716 & 1.6286 & - & 1 & 12 \\
\hline
\end{tabular}

a Data Density is defined as ratio of nonzero expenditures to total observations.

b 29 households had a negative quality-adjusted price.

c 1 household had a negative quality-adjusted price.

1 household had a negative quality-adjusted price. 


\section{Procedure}

Because some households chose not to consume some commodity groups, the dependent variable could have a zero value for some observations. These nonpurchases could be due to household inventory or nonpreference. The possibility of the former becomes a reality the shorter the survey period-in this case, one week. Although the relatively broad aggregation of commodities combats this problem to a degree, we still encounter zero expenditures. Numerous studies have addressed the econometric implications of this zero-expenditure problem. Estimation techniques which fail to take into account the censoring of the dependent variables give rise to biased parameter estimates. This analysis employs a generalization of the Heckman procedure as described by Heien and Wessells and Heien and Durham to account for zero expenditures. They utilize a two-step estimation procedure that is computationally simple and provides consistent and asymptotically efficient parameter estimates.

First, from a probit regression, we determine the probability that a given household would purchase the good in question. From this information we compute the inverse Mills ratio

Table 3. Descriptive Statistics for Nonpoverty Status Households $(n=3,087)$

\begin{tabular}{|c|c|c|c|c|c|}
\hline Variable & Mean & $\begin{array}{l}\text { Standard } \\
\text { Deviation }\end{array}$ & Data Density & Minimum & Maximum \\
\hline \multicolumn{6}{|c|}{ Expenditures } \\
\hline FAFH & 31.187 & 35.021 & 0.8685 & 0 & 350 \\
\hline Beef & 6.6064 & 7.1407 & 0.8377 & 0 & 92 \\
\hline Pork & 3.7127 & 4.8327 & 0.6809 & 0 & 53 \\
\hline Chicken & 2.4833 & 3.7148 & 0.6408 & 0 & 100 \\
\hline Fish & 2.9281 & 5.8710 & 0.5319 & 0 & 70 \\
\hline Cheese & 2.3000 & 2.4594 & 0.7732 & 0 & 27 \\
\hline Milk & 3.3625 & 3.2625 & 0.9174 & 0 & 38 \\
\hline Fruits & 3.2773 & 3.8134 & 0.7982 & 0 & 57 \\
\hline Vegetables & 3.5274 & 3.4760 & 0.8452 & 0 & 31 \\
\hline Breakfast cereals & 2.0842 & 2.3890 & 0.7169 & 0 & 23 \\
\hline Bread & 1.6420 & 1.4559 & 0.8367 & 0 & 14 \\
\hline Fats and oils & 1.6252 & 1.5914 & 0.7658 & 0 & 19 \\
\hline \multicolumn{6}{|c|}{ Quality-Adjusted Prices } \\
\hline FAFH & 6.4277 & 4.1371 & - & $-0.3206^{\mathrm{b}}$ & 65.6210 \\
\hline Beef & 1.7995 & 0.7432 & - & $-0.6702^{\mathrm{c}}$ & 9.7177 \\
\hline Pork & 1.7790 & 0.6324 & - & 0.2409 & 7.6352 \\
\hline Chicken & 1.2452 & 0.6953 & - & $-0.2250^{\mathrm{d}}$ & 7.7679 \\
\hline Fish & 2.5834 & 1.0661 & - & $-1.1028^{\mathrm{e}}$ & 16.5140 \\
\hline Cheese & 1.6784 & 0.6912 & - & 0.0926 & 6.7734 \\
\hline Milk & 0.3489 & 0.1344 & - & 0.1063 & 2.0127 \\
\hline Fruits & 0.5679 & 0.2564 & - & 0.0150 & 4.3128 \\
\hline Vegetables & 0.7090 & 0.2339 & - & 0.1105 & 2.5314 \\
\hline Breakfast cereals & 1.5912 & 0.5398 & - & 0.0364 & 4.6593 \\
\hline Bread & 0.9368 & 0.3078 & - & 0.0570 & 3.2222 \\
\hline Fats and oils & 1.0475 & 0.3932 & - & $-0.1170^{\mathrm{f}}$ & 4.7877 \\
\hline \multicolumn{6}{|c|}{ Socioeconomic Variables } \\
\hline Income & 33,244 & 23,815 & - & 6,996 & 330,300 \\
\hline Household size & 2.7347 & 1.3434 & - & 1 & 9 \\
\hline
\end{tabular}

a Data Density is defined as the ratio of nonzero expenditures to total observations.

b 1 household had a negative quality-adjusted price.

c 3 households had a negative quality-adjusted price.

d 5 households had a negative quality-adjusted price.

c 9 households had a negative quality-adjusted price.

f 1 household had a negative quality-adjusted price. 
Table 4. Percentage of Households in Each Demographic Category

\begin{tabular}{lcc}
\hline Category & $\begin{array}{c}\text { Poverty } \\
\text { Status Group }\end{array}$ & $\begin{array}{c}\text { Nonpoverty } \\
\text { Status Group }\end{array}$ \\
\hline Region & 16 & 22 \\
$\quad$ Northeast & 22 & 27 \\
Midwest & 15 & 19 \\
West & 47 & 32 \\
South & & \\
Urbanization & 30 & 21 \\
Central City & 31 & 52 \\
Suburban & 39 & 27 \\
Non-Metropolitan & & \\
& & \\
Race & 27 & 1 \\
Black & 1 & 91 \\
Asian & 72 & \\
White & & \\
\hline
\end{tabular}

$\left(M R_{h i}\right)$ for the $h$ th household for the $i$ th commodity. All available observations are used for the probit analysis, where the dependent variable equals one if the expenditure is nonzero, and zero otherwise (denoted by $Z_{h i}$ ). Saha, Capps, and Byrne mathematically characterized the process. Denoting the normal cumulative density function by $\Phi$, they show that

$$
\begin{aligned}
\operatorname{pr}\left[Z_{h i}=1\right]= & \Phi\left(\mathbf{W}_{\mathbf{h}} \boldsymbol{\delta}_{\mathbf{i}}\right) \\
\operatorname{pr}\left[Z_{h i}=0\right]=1-\Phi\left(\mathbf{W}_{\mathbf{h}} \boldsymbol{\delta}_{\mathbf{i}}\right) & \\
& \quad i=1, \ldots, n ; h=1, \ldots, H
\end{aligned}
$$

where $\mathbf{W}_{\mathbf{h}}$ is a vector of regressors related to the purchase decision, and $\boldsymbol{\delta}_{i}$ is the coefficient vector associated with these regressors. The first-stage provides estimates of $M R_{h i}$ as follows:

$$
\begin{aligned}
& \hat{M R}_{h i}=\left\{\frac{\phi\left(\mathbf{W}_{\mathbf{h}} \hat{\boldsymbol{\delta}}_{\mathbf{i}}\right)}{\Phi\left(\mathbf{W}_{\mathbf{h}} \hat{\boldsymbol{\delta}}_{\mathbf{i}}\right)} \text { for } Z_{h i}=1\right\}, \\
& \hat{M R}_{h i}=\left\{\frac{\phi\left(\mathbf{W}_{\mathbf{h}} \hat{\boldsymbol{\delta}}_{\mathbf{i}}\right)}{1-\Phi\left(\mathbf{W}_{\mathbf{h}} \hat{\boldsymbol{\delta}}_{\mathbf{i}}\right)} \text { for } Z_{h i}=0\right\}
\end{aligned}
$$

where $\phi$ represents the probability distribution function. In the second stage, the inverse Mills ratio is used as an instrument that incorporates the censoring latent variable in estimation of an LES. All $H$ observations are used for the second-stage estimation.
Given that the commodities considered are broad food group classifications, the LES was used to obtain parameter estimates (Phlips). A separate demand system was estimated for each group. Each equation within the LES was augmented with the inverse Mills ratio to account for any bias resulting from zero values in the dependent variable. The demand functions derived from this specification are written as

(4) $p_{i h} q_{i h}=p_{i h} \gamma_{i}+\beta_{i}\left(Y_{h}-\sum_{j} p_{j h} \gamma_{j}\right)+\alpha_{i}\left(M R_{h i}\right)+v_{i}$

where $p_{i h} q_{i h}$ is the expenditure on the $i$ th commodity group by the $h$ th household; $p_{i h}$ is the quality-adjusted price of the $i$ th commodity group for the $h$ th household; $\gamma_{i}$ is the subsistence quantity of the ith commodity group; $p_{i n} \gamma_{i}$ is the subsistence expenditure level on the $i$ th commodity group for the $h$ th household; $Y_{h}$ is the total weekly food expenditures on all commodity groups; $Y_{h}-\Sigma_{j} p_{j h} \gamma$ is the supernumerary income, or budget remaining after subsistence expenditures for the $h$ th household; $\beta_{i}$ is the marginal share of supernumerary income for the $i$ th commodity group; and $M R_{h i}$ is the Inverse Mills Ratio for the $i$ th commodity group and for the $h$ th household.

The equation for fats and oils was omitted from system estimation to avoid singularity of the variance-covariance matrix of the disturbance terms. Because the LES is derived from a direct utility function, homogeneity and symmetry will hold at every point and need not be imposed (Phlips).

\section{Empirical Results}

Parameter estimates were obtained for each group using a nonlinear maximum likelihood estimation routine (tables 5 and 6). The only insignificant estimates (at the 5\% level) were selected parameters associated with the inverse Mills ratio (except for the estimate of $\gamma$ for FAFH in the poverty status group). In each of the respective groups, in accordance with theory, all $\gamma$ 's were positive, and all $\beta$ 's were positive and between zero and one. The subsistence consumption $(\gamma)$ of cheese exceeded the mean consumption of cheese in the poverty status group, the only theoretical violation in both estimations.

The $\beta$ parameters in the LES correspond to marginal budget shares, the fraction of an additional dollar of supernumerary total expenditure 
Table 5. Parameter Estimates for Poverty Status Households

\begin{tabular}{lcccc}
\hline & \multicolumn{4}{c}{ Parameter Estimates } \\
\cline { 2 - 5 } Commodity Groups & $\gamma_{i}$ & \multicolumn{1}{c}{$\beta_{i}$} & $\alpha_{i}$ & $\mathrm{R}^{2}$ \\
\hline Food away from home & 0.4562 & 0.5534 & 0.7073 & 0.7000 \\
& $(1.67)$ & $(36.44)$ & $(3.67)$ & \\
Beef & 2.1405 & 0.0990 & 0.0844 & 0.3373 \\
& $(13.00)$ & $(16.13)$ & $(0.60)$ & \\
Pork & 1.0590 & 0.0649 & 0.2494 & 0.2030 \\
& $(8.19)$ & $(13.03)$ & $(1.48)$ & \\
Chicken & 1.6245 & 0.0304 & -0.5580 & 0.2777 \\
& $(15.26)$ & $(10.89)$ & $(-4.97)$ & \\
Fish & 0.3251 & 0.0378 & 0.9387 & 0.1211 \\
Cheese & $(2.92)$ & $(6.19)$ & $(3.90)$ & \\
& 1.0083 & 0.0254 & -0.8034 & 0.3054 \\
Milk & $(13.77)$ & $(10.24)$ & $(-5.72)$ & \\
& 4.0201 & 0.0500 & 0.2169 & 0.1417 \\
Fruits & $(10.59)$ & $(13.98)$ & $(1.99)$ & \\
& 2.4318 & 0.0307 & -0.3181 & 0.1141 \\
Vegetables & $(10.28)$ & $(10.60)$ & $(-2.13)$ & \\
& 2.3187 & 0.0371 & -0.3662 & 0.1955 \\
Breakfast cereals & $(13.11)$ & $(13.36)$ & $(-3.30)$ & \\
Bread & 1.0383 & 0.0274 & -0.7247 & 0.3091 \\
& $(14.39)$ & $(11.59)$ & $(-5.75)$ & \\
Fats and oils & 1.2077 & 0.0186 & -0.3432 & 0.2782 \\
& $(16.72)$ & $(12.83)$ & $(-4.35)$ & \\
& 0.2868 & 0.0253 & - & - \\
\hline
\end{tabular}

Note: t-ratios are in parentheses.

Table 6. Parameter Estimates for Nonpoverty Status Households

\begin{tabular}{lcccc}
\hline & \multicolumn{4}{c}{ Parameter Estimates } \\
\cline { 2 - 5 } Commodity Groups & $\gamma_{i}$ & $\beta_{i}$ & $\alpha_{i}$ & $\mathrm{R}^{2}$ \\
\hline Food away from home & 0.6377 & 0.6863 & 0.3166 & 0.7717 \\
Beef & $(3.42)$ & $(96.14)$ & $(4.69)$ & \\
& 2.2028 & 0.0634 & 0.0179 & 0.2117 \\
Pork & $(28.38)$ & $(25.69)$ & $(0.26)$ & \\
& 1.2007 & 0.0350 & 0.1215 & 0.1018 \\
Chicken & $(19.54)$ & $(20.27)$ & $(1.41)$ & \\
Fish & 1.3360 & 0.0232 & -0.1661 & 0.1505 \\
& $(21.22)$ & $(17.16)$ & $(-1.82)$ & \\
Cheese & 0.4869 & 0.0335 & 0.7900 & 0.1168 \\
& $(8.53)$ & $(15.28)$ & $(6.28)$ & \\
Milk & 1.0566 & 0.0187 & -0.5290 & 0.2716 \\
Fruits & $(34.80)$ & $(22.87)$ & $(-9.55)$ & \\
& 5.2547 & 0.0322 & 0.0002 & 0.1244 \\
Vegetables & $(25.85)$ & $(25.80)$ & $(0.003)$ & \\
\multirow{2}{*}{ Breakfast cereals } & 2.8520 & 0.0350 & -0.0279 & 0.1139 \\
\multirow{2}{*}{ Bread } & $(20.73)$ & $(25.29)$ & $(-0.45)$ & \\
Fats and oils & 2.8155 & 0.0330 & -0.0438 & 0.1147 \\
& $(24.29)$ & $(26.23)$ & $(-0.72)$ & \\
& 1.1869 & 0.0152 & -0.8018 & 0.2656 \\
& $(32.24)$ & $(18.35)$ & $(-12.52)$ & \\
& 1.4718 & 0.0097 & -0.4612 & 0.2361 \\
& $(41.21)$ & $(18.44)$ & $(-11.52)$ & - \\
& 0.6615 & 0.0148 & - & - \\
\hline
\end{tabular}


spent on a particular commodity. The $\gamma$ parameters correspond to subsistence quantities. Using likelihood ratio tests, the estimates of both the marginal budget shares and the subsistence quantities differ significantly between the below-poverty and above-poverty income groups.

A full report of own-price and cross-price elasticities is available upon request. Uncompensated own-price elasticities are presented in tables 7 and 8 . All estimated own-price elasticities are less than zero. A comparison of the own-price elasticities shows small differences for chicken, cheese, fruits, vegetables, and fats and oils. Expenditure elasticities also are presented in tables 7 and 8 . Our results for price elasticities for breakfast cereals are not in accord with those of Jones, Chern, and Mustiful. The estimated expenditure elasticities range between zero and one, with the exception of the elasticity for FAFH. The expenditure elasticity for FAFH is greater than one for both groups.

Income elasticities, not expenditure elasticities, are at the heart of policy decisions. However, income elasticities are not directly ob-

Table 7. Elasticities for Poverty Status Households

\begin{tabular}{lccc}
\hline & \multicolumn{3}{c}{ Elasticities } \\
\cline { 2 - 3 } Commodity & Own-Price & Total Food Expenditure $^{\mathrm{b}}$ & Income $^{\mathrm{a}}$ \\
\cline { 2 - 4 } Food away from home & -0.9336 & 1.7432 & 1.1223 \\
Beef & -0.4478 & 0.7112 & 0.4578 \\
Pork & -0.4867 & 0.7563 & 0.4869 \\
Chicken & -0.2177 & 0.5596 & 0.3603 \\
Fish & -0.6124 & 0.7237 & 0.4659 \\
Cheese & -0.0094 & 0.5696 & 0.3667 \\
Milk & -0.5291 & 0.6597 & 0.4247 \\
Fruits & -0.3426 & 0.5615 & 0.3615 \\
Vegetables & -0.3220 & 0.5963 & 0.3839 \\
Breakfast cereals & -0.1084 & 0.5890 & 0.3792 \\
Bread & -0.2074 & 0.5161 & 0.3323 \\
Fats and oils & -0.7867 & 0.7197 & 0.4633 \\
\hline
\end{tabular}

Note: All respective elasticities are calculated using the sample means of the data. Mean quantities were obtained by dividing mean expenditure by mean quality-adjusted price.

${ }^{a}$ Uncompensated own-price elasticities calculated as $[\gamma(1-\beta) / q]-1$.

b Total food expenditure elasticities calculated as $\left(\beta^{*} Y\right) /\left(p^{*} q\right)$.

Table 8. Elasticities for Nonpoverty Status Households

\begin{tabular}{|c|c|c|c|}
\hline \multirow{2}{*}{$\begin{array}{l}\text { Commodity } \\
\text { Groups }\end{array}$} & \multicolumn{3}{|c|}{ Elasticities } \\
\hline & Own-Price ${ }^{a}$ & Total Food Expenditure ${ }^{b}$ & Income \\
\hline Food away from home & -0.9588 & 1.4246 & 0.6092 \\
\hline Beef & -0.4380 & 0.6213 & 0.2657 \\
\hline Pork & -0.4448 & 0.6102 & 0.2609 \\
\hline Chicken & -0.3456 & 0.6041 & 0.2583 \\
\hline Fish & -0.5848 & 0.7407 & 0.3167 \\
\hline Cheese & -0.2434 & 0.5255 & 0.2247 \\
\hline Milk & -0.4723 & 0.6197 & 0.2650 \\
\hline Fruits & -0.5231 & 0.6911 & 0.2955 \\
\hline Vegetables & -0.4528 & 0.6064 & 0.2593 \\
\hline Breakfast cereals & -0.1077 & 0.4729 & 0.2022 \\
\hline Bread & -0.1685 & 0.3832 & 0.1639 \\
\hline Fats and oils & -0.5800 & 0.5883 & 0.2515 \\
\hline
\end{tabular}

Note: All respective elasticities are calculated using the sample means of the data. Mean quantities were obtained by dividing mean expenditure by mean quality-adjusted price.

${ }^{a}$ Uncompensated own-price elasticities calculated as $[\gamma(1-\beta) / q]-1$.

b Total food expenditure elasticities calculated as $(\beta * Y) /\left(p^{*} q\right)$. 
tained from the LES. They are retrieved through the use of an auxiliary linear regression of total expenditure on income (Hymans and Shapiro; Manser; Capps, Tedford, and Havlicek). The income elasticity for total expenditure calculated from this auxiliary regression can then be used to calculate an income elasticity as follows:

$$
e_{I, i}=e_{Y, i} e_{Y, I}
$$

where $e_{l, i}=$ income elasticity for consumption for the $i$ th commodity; $e_{Y, i}=$ expenditure elasticity for consumption for the $i$ th commodity; and $e_{Y, I}=$ income elasticity for total expenditure on all commodities.

The aforementioned auxiliary regression was obtained for each income group. From these regressions income elasticities for total expenditure were calculated at the means of the data. For the lower-income group this value was 0.6438 , and for the higher-income group this value was 0.4276 . As expected, these values are less than one with the result that the calculated income elasticities are less than their corresponding expenditure elasticities.

Income elasticities (tables 7 and 8) are consistently higher for the poverty status group. Values range from zero to one, with the exception of the income elasticity of FAFH, which is greater than one for the poverty status group. FAFH for the poverty status group is a luxury good, but FAFH is a normal good for the nonpoverty status group. This result is in accord with previous work by Huang and Raunikar. Overall, the poverty status group was more responsive to changes in income than the nonpoverty group.

A useful feature of the LES is the estimation of subsistence quantities. Using these estimates and mean imputed prices, weekly and annual subsistence expenditures for the commodities were obtained (table 9). Total weekly subsistence expenditures are $\$ 24.30$ and $\$ 18.68$ for the nonpoverty group and the poverty group, respectively. The bulk of the difference is due to higher expenditures on FAFH by nonpoverty households. Commodity group subsistence expenditures, in general, are higher for nonpoverty households than for poverty households. An exception is subsistence expenditure on chicken, which is higher for households in the poverty group. Annual subsistence expenditures for the commodity groups totalled $\$ 971.36$ for poverty status households, accounting for approximately $14 \%$ of their annual before-tax income. The percentage was
Table 9. Subsistence Expenditures by Commodity Group

\begin{tabular}{lcc}
\hline & \multicolumn{2}{c}{ Mean Weekly } \\
& Subsistence Expenditures (\$) \\
\cline { 2 - 3 } Commodity & $\begin{array}{c}\text { Poverty } \\
\text { Status } \\
\text { Households }\end{array}$ & $\begin{array}{c}\text { Nonpoverty } \\
\text { Status } \\
\text { Households }\end{array}$ \\
\hline Food away from home & 1.81 & 4.10 \\
Beef & 3.27 & 3.96 \\
Pork & 1.80 & 2.14 \\
Chicken & 1.68 & 1.66 \\
Fish & 0.81 & 1.26 \\
Cheese & 1.73 & 1.77 \\
Milk & 1.44 & 1.83 \\
Fruits & 1.42 & 1.62 \\
Vegetables & 1.68 & 2.00 \\
Breakfast cereals & 1.63 & 1.89 \\
Bread & 1.12 & 1.38 \\
Fats and oils & 0.29 & 0.69 \\
\hline Weekly total & 18.68 & 24.30 \\
Annual total & 971.36 & $1,263.60$ \\
\hline
\end{tabular}

substantially less for nonpoverty households with expenditures of $\$ 1,263.60$, representing only $4 \%$ of annual before-tax income.

\section{Policy Implications}

The previously discussed results may be used in making food policy decisions. To illustrate, Pinstrup-Andersen, de Londoño, and Hoover estimated a matrix of demand elasticities of twenty-two food commodities in Cali, Colombia, for five income strata. On the basis of their estimates, changes in nutritional levels (measured in calories and protein) of different population income strata could be examined from shifts in individual food commodity supplies. Similarly, we could use the methodology described by Pinstrup-Andersen, de Londoño, and Hoover to estimate changes in levels of key nutrients such as iron, calcium, and calories, particularly for the poverty-status group.

Alternatively, for any commodity, $q_{i}$, given estimates of own-price, cross-price, and income elasticities, we may write

$$
\begin{aligned}
\% \Delta q_{i}=\sum_{j=1}^{n} \varepsilon_{i j} \% \Delta p_{j}+\eta_{i} \% \Delta y & \\
& (i, j=1,2, \ldots, n)
\end{aligned}
$$


where $\varepsilon_{i j}$ represents the various price elasticity estimates, and $\eta_{i}$ represents the estimate of the income elasticity for commodity $i$. Thus, given percentage changes in the prices of the various commodities as well as the percentage change in income, we may calculate the percentage change in quantity demanded for any commodity $i$. If we let $\% \Delta q_{i}=k$ and rewrite $\% \Delta q_{i}$ as $\left[q^{F}-q^{0}\right] / q^{0}=k / 100$, where $q_{i}^{F}\left(q_{i}^{0}\right)$ is the new (initial) equilibrium level of quantity demanded after (before) the change in prices and income, then we can ascertain the impact of changes in prices and income on levels of nutrient elements. If we let $\mu_{i}$ represent the nutrient content per unit of commodity $i$, then this impact is given as

$$
\mu_{i}\left(q_{i}^{F}-q_{i}^{0}\right)=\frac{\mu_{i} q_{i}^{0} k}{100}
$$

Estimates of $\mu_{i}$ for selected commodities are available from the USDA via the nutrient data bank (Life Sciences Research Office). With this framework, one is then in the position of ascertaining the relative nutritional impacts of alternative food, agricultural, and/or macroeconomic policies for low-income groups.

Finally, one could use these empirical results to estimate the minimum percentage change in income of the poverty status group to effectively eliminate particular nutritional deficiencies, conditional on various levels of percentage changes in prices. In the simplest case, if it is assumed that $\% \Delta p_{j}=0$ for all $j$, then $\% \Delta q_{i}=$ $\eta_{i} \cdot \% \Delta y$. Further, if $\mu_{i}\left(q_{i}^{F}-q_{i}^{0}\right)=\tau_{i}$ represents the recommended nutrient level (which may be similar to a RDA), then using equation (7) we have

$$
\eta_{i} \% \Delta y=\frac{\tau_{i}}{\mu_{i} q_{i}^{0}}
$$

Therefore, $\% \Delta y=\tau_{i} /\left[\mu_{i} \cdot q_{i}^{0} \cdot \eta_{i}\right]$. Hence, these empirical estimates could be used to design policies with the goal of improving human nutrition.

\section{Concluding Remarks}

Twelve food commodity groups were analyzed according to household poverty status. A Heckman two-step procedure for a system of equations was employed to account for bias introduced from nonexpenditure on given com- modities by a household. The second step of the estimation involved the use of the Linear Expenditure System. Parameter estimates were used to obtain subsistence expenditures, ownprice elasticities, expenditure elasticities, and income elasticities.

The results indicate that if the emphasis of policy analysis is centered on poverty status households then analysts should employ demand parameter estimates using observations indigenous to this income group, and not average estimates for the population as a whole. This analysis could be enhanced through a further partitioning of income groups, the use of adult equivalency scales in lieu of household size, or the use of particular sociodemographic variates.

\section{[Received December 1994; final revision received February 1996.]}

\section{References}

Blaylock, J.R. "Variety, Prices, and Food Status in Low-Income Households." Appl. Econ. 23(June 1991):1019-27.

Blaylock, J.R., and W.N. Blisard. "The Distribution of U.S. Income and Food Expenditures." J. Consum. Affairs 23(Winter 1989):226-42.

Capps, O., Jr., and J.H. Havlicek, Jr. "National and Regional Household Demand for Meat, Poultry and Seafood: A Complete Systems Approach." Can. J. Agr. Econ. 32(March 1984):93-108.

Capps, O., Jr., J.R. Tedford, and J. Havlicek, Jr. "Household Demand for Convenience and NonConvenience Foods." Amer. J. Agr. Econ. 67(November 1985):863-69.

Cook, C.M., and D.B. Eastwood. "Incorporating Subsistence into Hedonic Price and Nutrient Demand Equations." J. Consum. Affairs 26(Winter 1992):288-304.

Cox, T.L., and M.K. Wohlgenant. "Prices and Quality Effects in Cross-Sectional Demand Analysis." Amer. J. Agr. Econ. 68(November 1986):908-19.

Heckman, J.J. "Sample Selection Bias as a Specification Error." Econometrica 47(January 1979):153-61.

Heien, D., and C. Durham. "A Test of the Habit Formation Hypothesis Using Household Data." Rev. Econ. and Statist. 73(May 1991):189-99.

Heien, D., and C.R. Wessells. "Demand Systems Estimation with Microdata: A Censored Regression Approach." J. Bus. and Econ. Statist. 8(July 1990):365-71.

Huang, C.L., and R. Raunikar. "Effect of Consigned 
Income on Food Expenditures." Can. J. Agr. Econ. 33(November 1985):315-29.

Hymans, S., and H. Shapiro. "The Allocation of Household Income to Food Consumption." Five Thousand American Families-Patterns of Economic Progress, vol. 2. J.N. Morgan, ed. Ann Arbor MI: The University of Michigan, 1974.

Jones, E., W.S. Chern, and B.K. Mustiful. "Are Lower-Income Shoppers as Price Sensitive as Higher Income Ones?: A Look at Breakfast Cereals." J. Food Distrib. Res. (February 1994):82-92.

Life Sciences Research Office, Federation of American Societies for Experimental Biology. "Nutritional Monitoring in the United States-An Update Report on Nutrition Monitoring." Prepared for the U.S. Department of Agriculture and the U.S. Department of Health and Human Services, DHHS Publication No. (PHS) 89-1255, Public Health Service, Washington DC, September 1989.

Lutz, S.M., D.M. Smallwood, J.R. Blaylock, and M.Y. Hama. "Changes in Food Consumption and Expenditures in American Households During the 1980s." Washington DC: U.S. Department of Agriculture, ERS, Human Nutrition Information Service Statistical Bulletin No. 849, December 1992.

Manser, M. "Elasticities of Demand for Food: An Analysis Using Non-Additive Utility Functions Allowing for Habit Formation." S. Econ. J. 42(July 1976):879-91.

Nayga, R.M., Jr., and O. Capps, Jr. "Determinants of Food Away from Home Consumption: An Update." Agribus. 8(November 1992):549-59.

Pinstrup-Andersen, P., and E. Caicedo. "The Potential Impact of Changes in Income Distribution on Food Demand and Human Nutrition." Amer J. Agr. Econ. 60(August 1978):402-15.

Pinstrup-Andersen, P., N.R. de Londoño, and E. Hoover. "The Impact of Increasing Food Supply on Human Nutrition: Implications for Commodity Priorities in Agricultural Research and Policy." Amer. J. Agr. Econ. 58(May 1976):131-42.

Phlips, L. Applied Consumption Analysis. Amsterdam: North-Holland Publishing Company, 1983.

Rauniker, R., C.L. Huang, and J.C. Purcell. "The Changing United States Food Market.” Agribus. 3(January 1985):42-45.

Saha, A., O. Capps, Jr., and P.J. Byrne. "Calculating Marginal Effects in Models for Zero Expenditures in Household Budgets Using a HeckmanType Correction." Working paper, Texas A\&M University, 1994

Senauer, B. "Household Behaviour and Nutrition in Developing Countries." Food Policy 15(October 1990):408-17.

Senauer, B., E. Asp, and J. Kinsey. Food Trends and the Changing Consumer. CITY STATE: Eagan Press, 1991.

Timmer, C.P. "Is there Curvature in the Slutsky Matrix?" Rev. Econ. and Statist. 63(August 1981):395-402.

Wales, T.J., and A.D. Woodland. "Sample Selectivity and the Estimation of Labor Supply Functions." Int. Econ. Rev. 21(June 1980):437-68. 